\title{
Can you show you are a good lecturer?
}

Leigh N. Wood ${ }^{\mathrm{a}}$; Ansie Harding ${ }^{\mathrm{b}}$

${ }^{a}$ Macquarie University, Sydney, Australia

${ }^{\mathrm{b}}$ University of Pretoria, South Africa

\section{Abstract}

Measurement of the quality of teaching activities is becoming increasingly important since universities are rewarding performance in terms of promotion, awards and bonuses and research is no longer the only key performance indicator. Good teaching is not easy to identify and measure. This paper specifically deals with the issue of good teaching in mathematics at tertiary level-what good teaching is and how to measure it.

\section{Overview}

Measurement of the quality of teaching activities is becoming increasingly important because universities are rewarding performance in terms of promotion, awards and bonuses. Good teaching is not easy to identify and measure. It's not as hard to show that you are high-quality in research (though the mathematical sciences tend to have a lower publishing rate than some other disciplines) but how do you show that you are a good lecturer?

These are the days of the TLA (three letter acronym). In Australia, we have the RQF (Research Quality Framework), GDS (Graduate Destination Survey), CEQ (Course Experience Questionnaire) and KPIs (Key Performance Indicators). Now we may baulk at all these management tools; however we believe that they will become the reality as universities strive to improve their performance and, more significantly, to show that they have improved their performance. And there is money involved. The Australian Government funds universities for good performance on learning and teaching through 
the TLPF (Teaching and Learning Performance Fund-they needed four letters), as well as for research.

Money is available for staff. For example, at the School of Mathematics at the University of Pretoria (UP) in South Africa, top performing academic staff are rated on their performance in teaching, postgraduate supervision, research projects, managerial and administrative duties and service to the university and other scholarly activities, and are rewarded by means of an annual once-off non benefit-bearing performance bonus. The Department of Statistics at Macquarie University has a system where academics receive up to a 7.5\% loading depending on performance, in teaching, research and administration. There are other incentives to demonstrate good teaching, such as promotion, university teaching awards and Carrick Institute (Australian government) grants and fellowships. Many of us are lecturers in universities because we love the job and enjoy working with students. We are not necessarily motivated by monetary reward but by simply wanting to do a good job. One view of measuring teaching is to see it as an imposition to make us continually justify our worth, which has the effect of undermining academic freedom. Another approach is to work to develop and implement practices that will enhance learning.

The question is, how do you measure good teaching? But, before we can answer this question we need to know what good teaching is, and more importantly what good teaching in mathematics at university level is. We need to specify the principles of good teaching followed by processes of measuring that work for mathematics!

\section{What is good teaching?}

Does good teaching happen when the teacher is a good orator or gets students to work hard? Is a good teacher someone who takes time explaining concepts well or someone who compiles excellent notes? The answer is probably all of the above and more. An example of identifying good teaching practices in mathematics at university level is given by the Department of Mathematics and Applied Mathematics at the University of Pretoria, South Africa, where staff have identified a list of ten possible areas of 
excellence within teaching. This was as a result of reflection and discussion amongst the staff as well as reviews of literature.

It would be idealistic for someone to excel in all of the ten areas but more realistic to expect even the best teachers to excel in only a few of these. The purpose of this table is to embed good teaching in a framework. Before looking at processes of measurement we focus on factors that influence measurement.

\subsection{Factors that influence measurement}

We identify three factors: the aims, the audience and the accuracy of the measurement. First, the main aims in measuring teaching are:

- $\quad$ promotion and salary supplementation

- monitoring and improving the department/division/university performance

- monitoring and improving student learning.

The first of these aims is for personal advantage, the second for institutional advantage and the third for the benefit of the cause. These aims influence measurement; for example when going for promotion a premium would be placed on scholarliness and teaching of post-graduate courses yet when monitoring student learning, facilitation of mathematical thinking and learning would be emphasised.

The audience also influences the type of measurement. For example, if you are monitoring teaching for yourself, you may make informal notes at the end of each semester, but for a promotions committee more formal measures would be necessary. Types of audience include:

- lecturer herself

- students

- promotions committees

- $\quad$ supervisors (performance management)

- university

- government 
Accuracy of measurement is particularly problematic for teaching. Measurements have errors but generally quantitative measures are easier to collect and will give an overview, but will not necessarily have much depth. Qualitative measures are more difficult to collect and to analyse but often give greater depth. In section 3 we discuss some of the problems with student surveys.

We now consider processes for measuring good teaching from the perspective of two universities, tailored for mathematics.

\section{Processes for measuring good teaching}

\subsection{Student surveys}

Student surveys of teaching are the most common form of appraisal of teaching and are used at most universities. These may cover teaching, a particular subject or the whole degree program. Some universities (for example Macquarie University) have two student surveys, one to assess a staff member's teaching and the other to assess the subject. Some surveys are distributed by the staff member and others are controlled by administrators. As an overview, we start with the CEQ and GDS which are aimed at graduates.

The Course Experience Questionnaire and the Graduate Destination Survey are sent to all graduates of Australian universities and are weighted highly in the TLPF. The CEQ gives

graduates 30 statements and asks them to rank these using a Likert scale of 1 (strongly disagree) to 5 (strongly agree). The statements cover university facilities (for example, The library services were readily accessible), statements more directly related to teaching (My lecturers were extremely good at explaining things), graduate attributes (The course improved my written communication skills) and feedback (The teaching staff normally gave me helpful feedback on how I was going). The full survey is available on most university web sites. While we may complain about the reliability and validity of these statements and the responses (also, the response rate is falling in most universities), these 
data are being used to make decisions about degree programs at government and university level.

The Graduate Careers Council of Australia (GCCA) administers the Graduate Destination Survey which requests information about what a graduate is doing in the April or October following the completion of their studies. This survey covers such questions as whether they are working and what kind of work and starting salary or whether they are in full time study. The data can be sorted into majors and are available at the DEST Graduate website (http://www.gradsonline.edu.au/gradsonline/). Again it is worthwhile looking at the site and searching for mathematics. From the most recent survey (2006) 57\% of mathematics graduates were in further study. Of those who were looking for full time work, $71 \%$ were employed and of these, the top three occupations were: business professionals (43\%), other professionals (24\%) and clerical and sales (12\%). These data are based on responses from 316 people. The data from both these surveys are used by careers advisors in schools, by the Good University Guide, by government and by university management.

In the USA student surveys are big business because tenure and promotion are highly dependent on positive student responses in surveys. Do the student surveys portray the correct picture? There are many papers considering how best to survey students and discussing the factors that influence ratings and what student ratings are reliable. These papers are not specific to mathematics.

Do the lecturer's and students' opinions correspond? One study of 198 lecturers compared responses from students about a lecturer and responses by the lecturer 1 . They found that there was a

positive relationship between instructors' predictions and actual student ratings with respect to overall ratings and the ratings of three dimensions of teaching. Results also demonstrate a systematic trend whereby low-rated instructors tend to overestimate their student ratings, high-rated instructors underestimated ratings, and moderately rated instructors gave accurate predictions (p. 1). 
What is the influence of the student population? 'A number of student characteristics are found to impact upon student evaluations of teaching. These include the expected grade in the subject, student age, ethnicity and gender, along with perceptions of the evaluation process itself.' $\underline{2}$, p. 62]. So care needs to be taken when comparing different classes with different student populations. However Beran and Violata 3 found that

Students at a major Canadian university completed the Universal Student Ratings of Instruction instrument at the end of every course over a three-year period, providing 371,131 student ratings. Analyses of between-group differences indicate that students who attend class often and expect high grades provide high ratings of their instructors ( $p<0.001)$. In addition, lab-type courses receive higher ratings than lectures or tutorials, and courses in the social sciences receive higher ratings than courses in the natural sciences ( $p<0.001)$. Regression analyses indicated, however, that student and course characteristics explain little variance in student ratings of their instructors (<7\%). It is concluded that student ratings are more related to teaching instruction and behavior of the instructor than to these variables. (p. 593).

What is the influence of characteristics of the lecturer? Many papers have been written on this, dealing with gender, language background and experience. Ogier 4 found that lecturers whose first language was not English scored lower on student ratings. This was, however, not evident in humanities but prominent in the sciences where he postulated, based on the findings of others, that students found the computational subjects more difficult. This implies there should be caution comparing student surveys in different disciplines.

How many students should complete the questionnaire? Response rates should be as high as possible. Richardson 5, in a review of literature on student surveys of teaching, suggests that $60 \%$ of the student group who have satisfactorily completed the course is reasonable. 
Should results of student surveys be taken seriously? Richardson [5, p. 410] concluded that student feedback provides important evidence for assessing quality, that it can be used to support attempts to improve quality, and it can be useful to prospective students. Postgraduate groups and distance education students needed different survey instruments. His review found that many students and staff believed the results of the surveys were informative but that many teachers and institutions did not take the student feedback seriously enough to act upon it. Student feedback should be acted upon by the lecturer. For example, a lecturer could start the next semester by saying 'Based on the comments of students from last semester, I have started an electronic discussion board. Let me know what you think of it.'

Student surveys are but one means of data to show the quality of your teaching. A portfolio with different aspects of teaching strengthens your case for good lecturing. Here we also consider peer review, self review, reviews by department heads and external panels.

\subsection{Peer review and peer observation}

Peer review occurs when your colleagues review your teaching for quality assurance or for reward. Peer observation is different. It is not about auditing or reviewing teaching for the purpose of quality assessment. There is a significant difference between review and observation. Peer observation is for the purpose of professional development and the dissemination of good practice. It is important to consider these distinctions in discussions with staff, as many are defensive about the idea of peer review but are more enthusiastic about professional development of their teaching.

For an example of how peer review was used for judging an award for teaching excellence, based on the ten areas of excellence in teaching (table 1), we again refer to the Department of Mathematics and Applied Mathematics at the University of Pretoria. Although we recognize that it is impossible to perform well in all of these areas, someone who excels in at least two of these categories can be nominated for the annual departmental teaching award. Nominations are submitted by any staff member. The 
Teaching Award Committee, consisting of five members representing all layers of seniority in the department and elected for a two year period, sifts through the nominees, asks for additional input from relevant staff if required, and makes the appointment. At other universities, students are able to make nominations for teaching awards.

\section{(1) Facilitation of mathematical thinking}

Brings insight and understanding of mathematical topics to - students of varying backgrounds

Effectively shows a variety of applications to $\bullet$ students

Inspires students to be interested in problem solving

Links even the most elementary topics in mathematics to its • bearing on mathematics and applied mathematics at the cutting edge

(2) Facilitation of learning Develops critical thinking

Assists students in becoming independent learners •

Instils principles of time management, adherence to deadlines • and life long learning

(3) Course organization (especially for large classes)

Timely return of graded assessment tasks •

Useful and well-structured study guide •

Well-planned and well-executed practical session • programme

Effective and frequently updated website •

Skilful management of staff involved in the course •

(4) Student support

Successful tutor programme •

Accommodating for student queries •

Stimulation for gifted students •

(5) Innovation

Design of new courses •

At the forefront of new developments •

Recognized for innovation •

Use of media •

Attempts new teaching approaches and methods

(6) Postgraduate courses/students

Excellent supervision of students •

Strong leadership abilities 


\section{Ten areas of excellence in teaching Table 1.}

\section{(1) Facilitation of mathematical thinking}

Creative and interesting projects •

(7) Effective assessment

Effective use of a variety of assessment methods •

Effective use of formative assessment •

Solutions to problematic issues such as excessive time spent on • marking

(8) Scholarliness

Publishes teaching ideas •

Makes developed material available to colleagues •

Part of a community of teaching -

Awareness of differences in learning modes of students (active; • reflective; theoretical; pragmatic)

Shows knowledge of relevant applications •

(9) Attitude

Displays enthusiasm •

Inspires students •

Accommodating and pleasant towards fellow colleagues •

Adds value to courses involved with •

(10) Course development

Formulation of goals/outcomes •

Significant/critical inputs •

Production/revision of study material •

One good way to implement peer review is to have teams of three academics making a prerequisite chain. For example a lecturer who often teaches the first year of a sequence and one who teaches second year and another who teaches third. These lecturers can observe each others' classes and gain knowledge of the links and learning styles in each subject. For service subjects, peer observation of each others' classes can forge deeper links.

The University of Queensland has information on peer observation of teaching available at: http://www.tedi.uq.edu.au/evaluations/resources/peerReview.html. A good discussion of peer observation is available at http://www.heacademy.ac.uk/988.htm. While these are not directed specifically at mathematics, the page links contain many good ideas and procedures. 


\subsection{Head of Department (HOD) review}

Performance management has become a key phrase at universities. It is widely recognized that university staff are no longer willing to go the extra mile for personal satisfaction only and that monetary reward has become a driving force. It is therefore imperative to distinguish high performers appropriately. Research activities are fairly easy to measure and consequently research has been recognized and rewarded in the past whereas good teaching was expected of everyone but remained largely unrecognized. In most cases promotion happened on grounds of research alone. The wheel has turned and the trend nowadays is to recognize all rounders; academics who excel in all areas. Although criteria for performance evaluation are developed at university level, it is the task of the Head of Department to tailor the criteria to the specific subject and to personally rate the performance of each member of staff.

As an example of performance management we return to the University of Pretoria and focus specifically on the evaluation of teaching. At the University of Pretoria the following critical performance areas (CPAs) for all subjects are identified:

- Teaching

- Postgraduate supervision

- Research projects

- Further degree

- Staff mentorship

- Managerial and Administrative duties

- $\quad$ Service to university and other scholarly activities.

Performance in each of the CPAs is rated on a five point scale. For the Department of Mathematics, criteria have been identified for the CPA rating, given in table 2. 


\section{Criteria for five point CPA rating for Table 2. teaching Below expectation $<3$ Fails to meet the two requirements for the score 3}

According to expectation 3

Above expectation 4
Good students' • Well-executed teaching supported by Good external examiners' reports • feedback

Either

Recipient of the departmental Excellence in Teaching Award Or

Departmental recognition of at least two teaching initiatives such as the following:

Significant improvement in assessment procedure •

Development of a new module •

Textbook published/Excellent notes developed •

Successful development of an innovative teaching method which

- demonstrably improves teaching

Design and implementation of an innovative support system for

- $\quad$ students (such as a new tutoring system)

Excellent 5
University or national recognition for a teaching initiative such as the following:

UP Chancellor's Award for Teaching •

UP Teaching Innovation Award •

Note that the mathematics criteria were implemented for the first time at the end of 2006

and are still subject to change. One criticism is that the jump from a 3 score to a 4 score is too high and that the requirement of recognition for at least two teaching initiatives should be reduced to one. For clarification, in the 'According to expectation category' external examiners refer to a peer reviewer for every module. The external examiner could be from the department or from third year level from another university. In the 'Excellent category' the Chancellor's Award refers to a teaching award at university level of which two are awarded per year and the Teaching Innovation Award refers to an award from the Department of Teaching Innovation for which a candidate submits an innovative teaching project.

\subsection{External panels}

Panels of employers, external academics and perhaps government representatives can be useful in keeping an overview of the direction of a degree programme or teaching in a 
department. At most universities an external review is mandatory at fixed intervals. Such an external review can highlight ineffective teaching practices that had been accepted as a tradition for many years. An example of an external review report is available at http://www.up.ac.za/academic/maths/external/index.html. Outcomes of a panel can also be positively used to show that you are up-to-date with current industry requirements. This can give external endorsement of the teaching. Many industry representative bodies, such as Engineers Australia, have policies on mathematics learning for their members.

\subsection{Research and scholarship}

Moving outside your university and discipline by reading articles and attending conferences can open a new way of approaching teaching. By publishing yourself, you receive external critiques of your teaching methods and developments which lead to improvements. By entering the field of educational research you can demonstrate the impact of your teaching to a wider audience. This benefits the discipline as a whole by the dissemination of good practice and better knowledge of student learning.

\subsection{Self review}

Finally, we look at self review as a method of assessing how good a teacher you really are. Reflection on teaching and learning is an excellent way to improve your teaching. First, writing down your teaching aims, and perhaps philosophy, will get you thinking about what you are trying to do with the subject. Then during the semester, you can note problems and highlights that emerge. At the end of the semester, after the examination marking is completed, you can write a summary of the teaching and any thoughts on how to improve the process for the next semester or next lecturer.

\section{Conclusion}

Academics in the mathematical sciences take learning and teaching seriously. They prefer professional development that is tailored to their needs as mathematics lecturers 6 in the same way that their students prefer mathematics that is relevant to their needs. What we have presented in this paper is a selection of ways to review teaching that is adapted for mathematics departments. Not one way is best and it depends on the purpose. For 
example, peer observation is best for professional development but peer review is used for quality assurance. As with teaching objectives, it is essential to be clear about your aim before you review.

Evaluating teaching is difficult, but done well has the potential to benefit student learning. We need to make this evaluation appropriate for mathematics.

\section{References}

- 1. Nasser, F. and Freskob, B. (2002) Predicting student ratings: the relationship between actual student ratings and instructors' predictions. Assessment \& Evaluation in Higher Education 31:1 , pp. 1-18.

- 2. Worthington, AC (2002) The impact of student perceptions and characteristics on teaching evaluations: a case study in finance education. Assessment \& Evaluation in Higher Education 27:1 , pp. 49-64.

- 3. Beran, T. and Violato, C. (2005) Ratings of university teacher instruction: how much do student and course characteristics really matter?. Assessment \& Evaluation in Higher Education 30, pp. 593-601.

- 4. Ogier, J. (2005) Evaluating the effect of a lecturer's language background on a student rating of teaching form. Assessment \& Evaluation in Higher Education 30, pp. 477-488.

- 5. Richardson, JTE (2005) Instruments for obtaining student feedback: a review of the literature. Assessment \& Evaluation in Higher Education 30 , pp. 387-415.

- 6. Houston, SK, Wood, LN, Engelbrect, J., Harding, A., Kagesten, O., Holton, D. and Barton, W. (2006) Professional development of mathematics academics.. Proceedings of the 3rd International Conference on the Teaching of Mathematics at the undergraduate level John Wiley and Sons, Istanbul, Turkey 